\title{
Compensation for Drug Injury
}

\section{Problems both sides of the Atlantic}

\author{
RICHARD SMITH
}

Inevitably some people are going to be injured by modern manufactured products. Drugs are one of the best examples: no matter how many premarketing and postmarketing tests are conducted any effective drug will be capable of unexpectedly causing injury. Should a person injured by a drug be regarded as somebody struck by lightning and left to cope as best he can ? Or should he be compensated? If he is to receive compensation who should pay it: the doctor who prescribed the drug, the chemist who dispensed it, or the company that made it? Or should the State compensate such victims? And on what basis should compensation be paid: to everybody injured by a drug without their having to prove that somebody was at fault, or only on proof of fault? And should a compensation system be overseen by the courts, the insurance companies, or the State?

These are some of the important questions that underlie the problem of compensation for drug injury. Each society answers them in a different way: in New Zealand some people injured by drugs are compensated by the State, while in the United States compensation is overseen mostly by the courts. In England somebody injured by a drug will, like anybody else, be eligible for social security and free treatment from the National Health Service, and these are in themselves forms of compensation. If he wants more then he will have to turn to the courts, where he will encounter considerable difficulties, and so consumers' organisations have pressed for a change in the laws governing compensation for product injuries. In the United States too there is pressure to change the law. But the pressure comes not from consumers but from manufacturers who are concerned about the commercial impact of decisions made by American courts. The two continents are thus being pushed in opposite directions.

British Medical Journal, London WC1H 9JR RICHARD SMITH, BSC, MB, assistant editor

\section{Changing the law in Britain and Europe}

Two British bodies-the Law Commission ${ }^{1}$ and the Royal Commission on Compensation for Personal Injury (the Pearson Commission) ${ }^{2}$-and two European bodies-the European Economic Commission ${ }^{3}$ and the Council of Europe ${ }^{4}$ - have all proposed changing the laws governing compensation for product injury-that is, product liability laws.

Two present English laws are relevant to drug injury. If a person is injured by a drug that he has bought in a chemist's shop he can sue the chemist under the law of contract. But this law is essentially irrelevant to compensation for drug injury because few serious drug injuries result from such non-prescription drugs. If a person is injured by a prescribed drug he cannot sue under the law of contract because no contract exists. He can, however, sue the doctor, the chemist, or the manufacturer under the law of tort-the law that governs compensation for injuries caused by wrongful acts or omissions by individuals or institutions. This law covers events such as road traffic accidents and collisions at sea as well as alleged medical negligence. A person who alleges that he has been injured by a prescription drug will have to prove that the drug was defective, that the defect caused his injury, and that the doctor, the chemist, or the manufacturer failed in his duty to take reasonable carethat is, he was negligent. Causation and breach of duty are both difficult to prove in such circumstances.

The four bodies who have looked at the laws governing compensation for product injury have all recommended the introduction of strict liability in tort on the part of the manufacturer for an injury caused by his product. Under strict liability a person injured by a drug would not have to prove that the manufacturer was negligent but only that the drug was defective and that the defect caused his injury. The various bodies have defined their terms in different ways and allowed different defences, but the EEC proposals are the most important as these take precedence, and they have been debated in both the House of Commons and the House of Lords. ${ }^{5}$ Mrs Sally Oppenheim, the Minister for Consumer Affairs, has said that the 
present EEC proposals are unacceptable. Specifically, the Conservative Government wants a "state of the art defence," which means that a manufacturer would not be liable for injuries caused by a defect in his product that he could not have known about given the state of scientific knowledge at the time the product was made.

Certainly the law will change, but the details of the change depend on future negotiation and on which party is in power.The proposed changes have caused a great deal of controversy ${ }^{7-9}$ : the Consumers' Association and many lawyers are keen that the EEC proposals should be introduced undiluted, whereas most manufacturers-particularly drug companies-are unhappy with them.

What is not clear, however, is what will actually happen if strict liability in tort for product injury is introduced. Both proponents and opponents have made loud and perhaps exaggerated predictions, but the predicted and intended effects of new laws are often very different from what actually happens when the law is introduced. Consumers have argued that if the proposals are not introduced many injured people will not be adequately compensated and some will not be compensated at all. They say that if a "state of the art" defence is allowed people such as those injured by thalidomide would not be compensated. Manufacturers have argued that if the EEC proposals are introduced costs will soar. Both drug companies and doctors argue that the proposals will be unworkable for drugs yet may have dire effects on the practice of medicine in Britain. ${ }^{78}$

\section{Old hat in the United States}

To understand more about what might happen in Britain if strict liability is introduced I went to the United States to study its system. Curiously, both sides in the British controversy quote American experience to illustrate their cases. For various reasons (foremost among them the absence of a free health service) compensation through the courts for product-induced injury is much more important in the States than in Britain. Americans have had almost 20 years' experience of strict liability in tort for product-induced injury: it first appeared as part of the common law in California in 1963 and was adopted in the Restatement (Second) of the Law of Torts in 1965. It is essentially a matter of State law, so judges and juries within 50 different jurisdictions have produced a wide range of decisions. Indeed, in product liability law the United States might be seen as one great legal laboratory, and there are lessons for Britain to learn.

In America I met lawyers and representatives of the medical profession, the Government, and the drug industries to talk about the issues. I also looked extensively at papers and books on the issue in the United States. The number of documents is enormous: the Federal Interagency Task Force report on product liability is in seven volumes ${ }^{10}$; and the main textbook on product liability in America comes in six volumes and occupies about two feet of shelf space."1 These are only two of many relevant books, reports, and journal articles (there is even a journal devoted entirely to product liability).

\section{Provisos to comparison}

What has happened in the United States will not happen in the same way here, but we can learn a lot from American experience. Although the American legal system grew directly out of the English system, cultural and other differences have made the interpretation and development of the law quite different.

Firstly, in contrast to English cases, American product liability cases are usually tried by jury, and the jury decides the amount of the damages. Juries are perhaps more likely to be swayed by emotion than judges, and they must also find it difficult to grasp the legal and scientific complexities of the cases.
Secondly, the contingency-fee system, whereby plaintiffs do not pay anything if they lose and the lawyers take a proportion of the damages (usually between a third and a half) if they win, means that more cases are started. Thirdly, punitive damages may be awarded in some cases, which may mean enormous payments. Fourthly, the welfare state is less developed than in Britain, which means that injured individuals may look to the courts to compensate them for items such as medical expenses. Fifthly, the Freedom of Information Act gives access to information that might not be available in England.

Nevertheless, the United States is the home of strict liability in tort, and only there can we find a fully developed tort system of compensating injured people-and that is the system that Britain and Europe are choosing to adopt. Perhaps what we see there will encourage us to look to New Zealand, which has one of the few no-fault systems of accident compensation. In a no-fault system the injured person is compensated from a fund without having to take legal action against anybody. In New Zealand a central fund is administered by the Government.

\section{Submerged principles}

Each society arrives at its own system for compensating people injured by products. These systems depend on the way that the societies answer certain fundamental questions: too often these fundamental questions are submerged under legal and administrative complexities. The next article will consider American experience more specifically, but I want here to discuss some of the underlying questions.

Is it right that a young woman who has pelvic cancer which is said to be caused by diethylostilboestrol (DES) should receive $\$ 500000$ while a woman with the same condition and yet no obvious cause receives nothing ? Even when women are compensated, why should one receive $\$ 150000$ and another $\$ 800000$ ? If some people are to be compensated for product injury when nobody is at fault (as is the case with strict liability in tort) is it not reasonable to compensate for other losses that are nobody's fault ? Being born disfigured, being ugly, being stupid, living in miserable conditions: should all of these be compensatable?

A person may be damaged by disease, by an accident that is nobody's fault, or by an accident that is somebody's fault. There seems to be justice in somebody who is knocked down by a drunken driver being compensated by that driver. Tort law was devised for such a straightforward incident. In the United States at least, that law has now been stretched to cover accidents in which nobody is at fault. Many lawyers regard this as a great achievement. Richard A Epstein, a professor of law in Chicago, has written: "Viewed from inside the legal profession the growth of the modern products liability law is a triumph of the common law." 12 The achievement lies in injured people who would not previously have been compensated receiving money for their injury. The argument is that the manufacturer or doctor can take out insurance, raise the cost of their products or services, and thus "spread the loss." An individual is unlikely to take out insurance against being injured by a drug, but manufacturers can easily insure so that the handful of people inevitably injured by their products can be compensated. The courts also argue that manufacturers are in the best position to reduce the number of injuries to a minimum.

Thus the relevant question to many courts has not been who is at fault but who can best pay compensation: the courts are working a kind of social insurance system. This change of emphasis may, however, fail to solve old problems at the same time as creating new ones. Firstly, it still means that although some injured people are generously compensated others-those who have no hope of "pinning" their injury on anyone-get nothing. Secondly, it is an inefficient and arbitrary system. Cases take years to settle, the results are something of a lottery, and, as the Interagency Task Force showed, more money is spent in running the system than is ever paid out in compensation. Thirdly, it has been argued that government policy may be 
disrupted. For instance, the cost of drugs may be increased at a time when governments are worried about expenditure on drugs. Fourthly, some companies may be forced into bankruptcy or trade without insurance (though there is no evidence that this has happened to drug companies).

\section{Causation and compensation}

The problem of causation is crucial in all legal liability, but particularly in the case of liability for drug injury. If some people are to receive several hundred thousand dollars compensation for a cancer caused by a drug, yet other people with the same cancer but no obvious cause are to receive nothing, there is a strong incentive for the person with no cause to try to find one. Many drugs have adverse reactions that are the same as naturally occurring disease; indeed, doctors may realise that a drug has such a reaction only after statistical analysis. The classic example, but there are many thousands of others, is a woman on the contraceptive pill who has a stroke. How can anybody decide whether that stroke was "caused" by the pill ? Nobody can, nor can anybody decide how important were the facts that she smoked and was overweight and hypertensive.

Although a woman taking the pill who has a stroke is the example commonly used to illustrate the problems of causation, in many ways it is a poor one. A stroke is a well-known adverse reaction to the pill and manufacturers will provide warnings about it. The problem of causation is more important when somebody thinks he can link an unexplained illness to a drug. The best example of this kind of wrangle over causation is with the antinauseant drug Debendox (sold as Bendectin in the United States). This drug is alleged to cause malformations in the babies of mothers who take it during pregnancy. Despite large studies showing no overall increase in the incidence of malformations in the children of women who took the drug in early pregnancy, the court - and the jury-may well be swayed by persuasive argument when about to decide whether a particular child was injured by the drug.

This problem of causation persists through almost all compensation systems. Only in a system where money was paid to all who had strokes, all babies born with malformations, or, indeed, anybody suffering any ill would the problem be avoided. The National Health Service and the social security system come close to being such systems, but a so-called no-fault compensation system such as the one in New Zealand compensates only those injured in accidents. Thus a child born with a malformation caused by a drug might be eligible for compensation but not one whose malformation was just "one of those things."

Compensation through the courts can never result in each injured person receiving benefits "according to his need." Only a change in social attitudes followed by legislation backed up by adequate funds could achieve such an equitable system. The courts have done their best to help the injured people who come their way, but few problems have been solved and many have been created. The next article will consider how American product liability law has developed and a third will consider American attempts to improve the compensation system and compare these with European attempts to do the same thing.

\section{References}

1 Law Commission. Liability for defective products. London: HMSO, 1977. (Cmnd 6831)

${ }^{2}$ Royal Commission on Civil Liability and Compensation for Personal Injury. Report. London: HMSO, 1978. (Cmnd 7054-1, 2, and 3: Pearson Report).

${ }^{3}$ European Economic Commission. Amendment of the proposal for a Council directive relating to the approximation of the laws, regulations, and administrative provisions of the member states concerning liability for defective products. Brussels: EEC, 1979.

4 Council of Europe. Convention on product liability. Strasbourg: Council of Europe, 1977

5 Hansard. House of Commons. 4 November 1980, col 1106

6 Hansard. House of Lords, 12 November 1980, col 1393.

7 Anonymous. Product liability. Br Med f 1979;i:1663-4.

8 Anonymous. Unwanted drug effects: whose responsibility ? Lancet 1979 ii:21.

- Young R. Product liability: are industrialists protesting too much. The Times 1980, March 6.

10 Federal Interagency Task Force on Product Liability and Accident Compensation. Report. Washington: United States Department of Commerce, 1977.

11 Frumer L, Friedman M. Products liability. New York: Bender, 1978.

12 Epstein RA. Products liability: the search for the middle ground. North Carolina Law Review 1978;56:643-62.
As three-month colic appears to be commoner in breast-fed infants might this serve as a protective function in the young animal, encouraging suckling and clinging in the early days of extrauterine life? Is there some substance in breast milk that stimulates smooth muscle and is inhibited by suckling or some other secretion?

Levine and Bell ${ }^{1}$ wrote 30 years ago that evening colic was sometimes relieved by the use of a "pacifier" or "dummy," and might therefore represent "an unsatisfied need for adequate oral gratifications." I have been unable to confirm this. I have the clinical impression, which I have not confirmed statistically, that evening colic is more common in breast-fed babies. I wonder whether prostaglandins, present in considerable quantities in human milk, ${ }^{2}$ some of them known to be related to contraction of smooth muscle, or one or more of the 200 or so gut hormones, ${ }^{3}$ such as motilin, neurotensin, pancreatic polypeptides, and enteroglucagon, significantly different in breast-fed and bottle-fed babies, may be related to evening colic. I believe that before long research on the above will solve the riddle of evening colic. Somehow the solution must fit in with the relief that the anticholinergic drug dicyclomine hydrochloride invariably provides $^{4} 5$ in babies with symptoms typical of the condition.

${ }^{1}$ Levine MI, Bell AI. The treatment of Colic in infancy by use of the pacifier. $f$ Pediatr 1950;37:750-5.

Lucas A, Mitchell MD. Prostaglandins in human milk. Arch Dis Child 1980;55: 950-2.

Lucas A, Blackburn AM, Aynsley-Green A, Sarson DL, Adrian T, Bloom SR Breast vs bottle: endocrine responses are different with formula feeding. Lance $1980 ; \mathrm{i}: 1267-9$.

- Illingworth RS. Evening colic in infants. A double-blind trial of dicyclomine hydrochloride. Lancet 1959 ;ii;1119-20.

af the efficacy of dicyclomine hydrochloride syrup in the treatment of infantile colic. Curr Med Res Opin 1977;5:258-61.

\section{Are pigeons roosting around buildings a health hazard to the occupants?}

Pigeons roosting around buildings are probably more a nuisance than a health hazard, although they may be carriers of certain diseases communicable to man. One of these is psittacosis or ornithosis, which is caused by a virus-like micro-organism and is often associated with members of the parrot family, although it also occurs in pigeons, chickens, ducks, and pheasants. It has been estimated that $90 \%$ of the pigeons in Trafalgar Square are carriers of the organism without showing any apparent signs of the disease. During 1945-65, 100 human cases of acute respiratory infections with organisms of the psittacosis group were seen in South Bedfordshire and North Hertfordshire. Such infections often occur among pigeon fanciers. ${ }^{1}$ Railway guards have been infected from racing pigeons in crates in their vans, ${ }^{2}$ and as many as 500 cases of human psittacosis, 19 of them fatal, may have been caused by the breeding and transport of racing pigeons. ${ }^{3}$ Yet the pigeon strain of the organism is probably not very virulent to man and there is no evidence of tourists becoming infected in Trafalgar Square, though they may well be breathing the organisms in aerosol concentrations. ${ }^{4}$ Nevertheless, airborne infections to people from heavy densities of pigeons might be possible. The control of the number of pigeons in city and urban localities is the responsibility of the local government authority.

\footnotetext{
Scott WN. Diseases of animals communicable to man. Biology and Human Affairs $1967 ; 32: 2-9$

' Dew J, Mawson K, Ellman P, Brough D. Ornithosis in two railway guards: a occupational hazard. Lancet 1960 ;ii:18-9.

Meyer KF. In: Horsfall FL, Tamm I, eds. Viral and rickettsial infections of man. London: Pitman, 1965

Christie AB. Infectious diseases: epidemiology and clinical practice. Edinburgh: Livingstone, 1969 .
} 